\title{
A rare cause of dyspnea and palpitations: mediastinal schwannoma
}

\author{
Rzadki przypadek duszności i kołatania serca - schwannoma
}

\author{
Gulacan Tekin ${ }^{1}$, Mehmet Ozgel$^{2}$, Yusuf Kenan Tekin ${ }^{3}$, Ali Rıza Erbay ${ }^{1}$ \\ ${ }^{1}$ Bozok University, Faculty of Medicine, Department of Cardiology, Yozgat, Turkey \\ ${ }^{2}$ Government Hospital, Department of Thoracic Surgery, Malatya, Turkey \\ ${ }^{3}$ Yozgat State Hospital, Emergency Department, Yozgat, Turkey
}

Kardiochirurgia i Torakochirurgia Polska 2012; 9 (4): 468-470

\begin{abstract}
A 65-year-old woman presented with worsening of respiratory discomfort and palpitations for two months. Echocardiography revealed a mediastinal mass compressing the left atrium which measured $61 \times 47 \mathrm{~mm}$. Computed tomography (CT) and magnetic resonance imaging (MRI) showed a well-circumscribed mass with hypointense septation located between the left atrium and descending aorta and adjacent to the esophagus. We report a very rare case of the left atrium compressing a mediastinal tumor which was a schwannoma.
\end{abstract}

Key words: mediastinal mass, schwannoma.

\section{Introduction}

Schwannomas are nerve myelin sheath tumors and the majority of them are benign. These tumors are mostly localized at the central nervous system, extremities, neck, mediastinum and retroperitoneum but can be detected anywhere in the body. Central nervous system localization is the most common and especially the eighth cranial nerve is affected. Schwannomas are usually asymptomatic until they reach significantly large sizes and symptoms are generally dependent on the compressing adjacent structures [1-3]. We present here a very rare case with complaints of palpitations and dyspnea due to posterior mediastinal schwannoma compressing the left atrium.

\section{Case report}

A 65-year-old woman was admitted to the hospital with complaints of intermittent episodes of dyspnea, and palpitations for 2 months. She also complained of an atypical

\section{Streszczenie}

W pracy przedstawiono przypadek 65-letniej kobiety z nasileniem duszności i kołatania serca od 2 miesięcy. W badaniu echokardiograficznym stwierdzono obecność masy w śródpiersiu o wymiarach $61 \times 47$ mm uciskającej lewy przedsionek. Tomografia komputerowa (computed tomography $-\mathrm{CT}$ ) i rezonans magnetyczny (magnetic resonance imaging - MRI) wykazały obecność dobrze zorganizowanej masy z hipotensyjnym ograniczeniem, umiejscowionej pomiędzy lewym przedsionkiem a aortą zstępującą i przylegającej do przełyku. Opisano bardzo rzadki przypadek ucisku lewego przedsionka przez guz śródpiersia, którym była schwannoma.

Słowa kluczowe: masa w śródpiersiu, schwannoma.

chest pain regardless of activity. Her dyspnea and palpitations worsened with time. She had a normal pulse rate and a regular rhythm, and her blood pressure was 120/70 $\mathrm{mm} \mathrm{Hg}$. No murmur or thrill was detected. Hematologic test results were within normal limits. Electrocardiogram was negative for ischemia. Chest $\mathrm{X}$-ray did not reveal pulmonary vascular congestion, pulmonary edema, or cardiomegaly. Two-dimensional echocardiography showed a mass causing left atrial compression. Short axis mass diameter was $66 \times 41 \mathrm{~mm}$, whereas apical diameter was 50x46 mm with two-dimensional echocardiography (Fig. 1). A fat density tumor in the mediastinum compressing the left atrium was found by chest computed tomography (CT) and magnetic resonance imaging (MRI) (Fig. 2). The tumor was homogeneous, well circumscribed, with hypointense septation and was located between the left atrium and descending aorta, adjacent to the esophagus, immediately enhanced with contrast medium, rich in fat and showed no apparent 

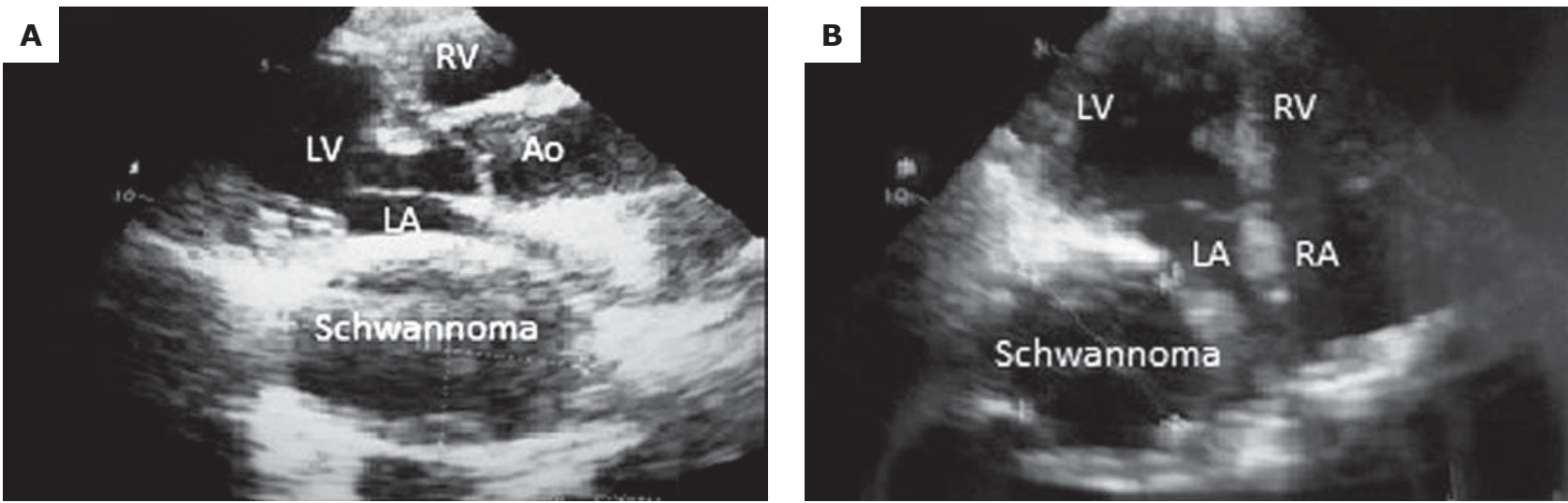

Fig. 1A-B. Compression of the left atrium is shown by echocardiography. A) is parasternal long axis and B) is apical 4 dimension image. Compressed left atrium is seen in both images. LV - left ventricle; LA - left atrium; RV - right ventricle; Ao - aorta
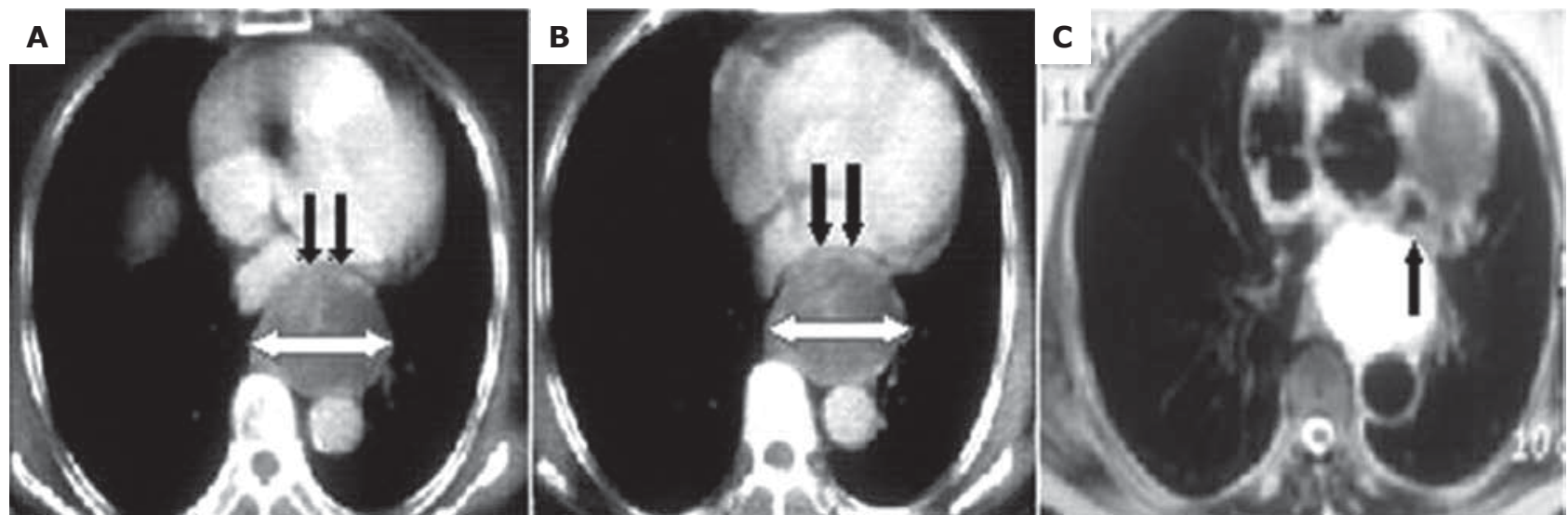

Fig. 2A-C. A) and B) are computed tomography images. White arrow shows diameter of schwannoma and black arrows show compression of left atrium. C) is an MRI image and it also shows compression of the left atrium (black arrow)

invasion into surrounding tissues. The patient underwent a left posterolateral thoracotomy and the tumor was removed completely. Due to adjacent major vascular structures, resection was done carefully but the tumor mass was well circumscribed and not invading the adjacent structures. Histopathological examination of the tumor material showed that the tumor was consistent with a benign schwannoma, characterized by proliferation of spindle cells with cellular uniformity and immunohistochemically the tumor cells were positive to S-100 protein.

\section{Discussion}

Schwannomas are the most common peripheral nerve tumors [1, 4]. Neurogenic tumors represent $15-20 \%$ of primary mediastinal tumors and less than half of them are schwannomas [4]. Acoustic neuroma is the most commonly seen schwannoma and its derivation is cranial nerve VIII [5]. Schwannomas originating from the vagus nerve within the mediastinum are rare, comprising only $1.4 \%$ of intrathoracic schwannomas [6].

Schwannomas can be seen at any age although they are more frequent over forty and can be seen in men and women equally [7]. Schwann cells are glial cells of the peripheral nervous system that are located in the axon, produce myelin for the axons and serve and separate nerve cells from adjacent structures. Schwannomas originate from Schwann cells and diagnosis of these tumors is usually delayed and most often incidental due to nonspecific symptoms related to compression or invasion of adjacent structures [5]. Our case was diagnosed while searching for the cause of dyspnea, palpitations and atypical chest pain.

Histologically, schwannomas are lobulated, encapsulated, firm, fusiform-shaped cells, highly vascular, homogeneous, featuring no atypia, mitoses, increased cellularity or necrosis $[7,8]$. They are rarely malign and most of these malign tumors are seen in patients with neurofibromatosis. Microscopic examination of malign schwannoma is characterized by atypia, mitoses, pleomorphism and necrosis [7]. In our case pathologic examination revealed benign schwannoma.

Radiologically these tumors have smooth margins and rarely show cystic degeneration, cavity formation, necrosis, or calcification. In preoperative evaluation, $C T$ and MRI are useful for diagnosis of these tumors [7, 8]. Schwannomas 
appear in CT as a homogenous mass with heterogeneous contrast enhancement. The MRI findings of these tumors are hypointense or isointense on T1-weighted images and inhomogeneous high signal intensity on T2-weighted images [5]. In our case the tumor was first recognized in echocardiographic examination and both CT and MRI scans were performed for detection of its features.

Due to the possibility of malignancy when a schwannoma is detected, total resection is recommended for the treatment and video-assisted thoracoscopy is also a possibility. If the tumor is incompletely resected, recurrence could occur $[9,10]$. In our case, the tumor was completely resected, and the patient had no postoperative complications and no complaints of dyspnea or palpitations during 6-month follow-up.

In conclusion, benign schwannomas of the vagus nerve are very rare. Patients with thoracic schwannomas could attend cardiology departments with complaints of dyspnea, palpitations and chest pain due to compression of the heart. Complete resection is a curative surgery for schwannomas.

\section{Literature}

1. Rammos KS, Rammos SK, Foroulis CN, Zaramboukas TK. Schwannoma of the vagus nerve, a rare middle mediastinal neurogenic tumor: case report. J Cardiothorac Surg 2009; 4: 68.

2. Kulkarni N, Andrews SJ, Rao V, Rajagopal KV. Case report: Benign porta hepatic schwannoma. Indian J Radiol Imaging 2009; 19: 213-215.

3. Dutta R, Kumar A, Jindal T, Tanveer N. Concurrent benign schwannoma of oesophagus and posterior mediastinum. Interact Cardiovasc Thorac Surg 2009; 9: 1032-1034.

4. Stouffer CW, Allan RW, Shillingford MS, Klodell CT. Endobronchial schwannoma presenting with bronchial obstruction. Interact Cardiovasc Thorac Surg 2010; 10: 133-134.

5. Ortigara L, Rosemberg N, Siqueira R, Neto F. Resection of a mediastinal schwannoma using video-assisted thoracoscopy. J Bras Pneumol 2006; 32: 172-175.

6. Heras F, Ramos G, Castanedo M, Cortejoso A, Duque JL, Yuste MG. Schwannoma of the intrathoracic vagus nerve. Arch Bronconeumol 1997; 33: 360-362.

7. Strollo DC, Rosado-de-Christenson ML, Jett JR. Tumors of the middle and posterior mediastinum. Chest 1997; 112: 1344-1357.

8. Jung JH, Joo KR, Chae MJ, Jang JY, Lee SG, Dong SH, Kim HJ, Kim BH, Chang YW, Lee Jl, Chang R, Kim YH, Lee SM. Extrahepatic biliary schwannomas: a case report. J Korean Med Sci 2007; 22: 549-552.

9. Sakurai H, Hada M, Mitsui T, Ashizawa I. Extrathoracic neurilemoma of the lateral chest wall mimicking a subcutaneous tumor: report of a case. Ann Thorac Cardiovasc Surg 2006; 12: 133-136.

10. Yamaguchi M, Yoshino I, Fukuyama S, Osoegawa A, Kameyama T, Tagawa T, Maehara Y. Surgical treatment of neurogenic tumors of the chest. Ann Thorac Cardiovasc Surg 2004; 10: 148-151. 